\title{
Diversity and Habitat Selection of Wetland Birds in Nilgiris, South India
}

\author{
Veeramani $A^{1}$, Vinoth $B^{1}$, Ramakrishnan $B^{2}$, Mohanakrishnan $\mathbf{H}^{2}$ and \\ Samson $\mathrm{A}^{2}$ \\ 1Department of Zoology, Government Arts College (Autonomous), India \\ 2Department of Zoology and Wildlife Biology, Government Arts College, India
}

\section{Research Article}

Volume 1 Issue 3

Received Date: July 16, 2018

Published Date: July 31, 2018

*Corresponding author: Veeramani Arunachalam, Assistant Professor of Zoology, PG and Research Department of Zoology, Government Arts College (Autonomous), Kumbakonam - 612 002, Tamil Nadu, India, Tel: 8124881520; Email: wildveera@gmail.com

\section{Abstract}

Wetlands are defined as transitional lands between terrestrial and aquatic eco-systems where the water table is usually at or near the surface or the land is covered by shallow water. Water birds are an important component of most of wetland environment, as these occupy several trophic levels in the food web of wetland nutrient cycles also wetland, birds play a significant cultural and social role in local communities as well as being an important component of wetland ecosystem. The study sites are selected adjacent to Gudalur Taluk of Nilgiris, Tamil Nadu. Bird population was estimated using total count method. Food and feeding behavior was investigated using the observational method. Pond ecosystem is mostly preferred by the water birds followed by river and stream habitats. Overall analysis of the birds sighted in five month periods shown that the cattle egrets were sighted more in number. More number of birds seen in pond followed by river and stream. Very few bird species were seen in agricultural fields. The study proved that if the present ecological characteristics of wetland continue, the birds were unable to inhabit this habitat in the immediate future. Proper awareness regarding the importance of birds to the local people, through different programmes will ultimately help the protection of birds of this region.

Keywords: Nilgiris; Wetland Birds; Habitat; Total Count; Food \& Feeding

\section{Introduction}

Wetlands are defined as transitional lands between terrestrial and aquatic eco-systems where the water table is usually at or near the surface or the land is covered by shallow water [1]. Wetlands are among the most productive ecosystems in the world and play a vital role in flood control, aquifer recharge, nutrient absorption and erosion control. In addition, wetlands provide home for a huge diversity of wildlife such as birds, mammals, fish, 


\section{International Journal of Zoology and Animal Biology}

frogs, insects and plants [2]. Thus wetlands help in maintaining biodiversity of flora and fauna.

Wetlands are also a complex and productive ecosystems that occupy about six percent of the Earth's land surface [3-5]. Hence, wetlands are known as "biological supermarkets" because of the extensive food chains and rich biodiversity that they support, providing unique habitats for a wide range of flora and fauna [6]. They also important habitats for water birds, which use them for feeding, roosting, nesting and rearing young $[7,8]$. And also used by water birds for breeding, feeding or shelter during their breeding cycles.

Water birds are an important component of most of wetland environment, as these occupy several trophic levels in the food web of wetland nutrient cycles. In wetland, birds play a significant cultural and social role in local communities as well as being an important component of wetland ecosystem.

\section{Objectives}

The study was carried out from August 2013 to February 2014 with the following objectives

a) To determine the status and distribution of wetland birds in the study area

b) To find out the food and feeding habits with special emphasis on habitat selection

c) To identify the conservation problems facing the wetland birds.

\section{Study Area}

The study sites include Chundi, Bennai, Padanthurai, Puliyamparai and Thorapally regions are adjacent to Gudalur Taluk of Nilgiris, Tamil Nadu. The wetlands such as ponds, rivers, streams and agriculture fields are predominantly seen in these regions are given in the Table 1.

\begin{tabular}{|c|c|c|c|c|c|c|}
\hline SI No & Region & Villages & River & Stream & Pond & Agri. Field \\
\hline 1 & \multirow{2}{*}{ Chundi } & Periyar Nagar & $\mathrm{P}$ & & & \\
\hline 2 & & Hope & & $\mathrm{P}$ & & \\
\hline 3 & \multirow{2}{*}{ Bennai } & Athikunni & & $\mathrm{P}$ & & \\
\hline 4 & & Chepodu & & $\mathrm{P}$ & & \\
\hline 5 & \multirow{5}{*}{ Padanthurai } & Chundavayal & & & $\mathrm{P}$ & \\
\hline 6 & & Marakarai & $P$ & & & \\
\hline 7 & & Ponvayal & & & $\mathrm{P}$ & \\
\hline 8 & & Angankalari & & & & $\mathrm{P}$ \\
\hline 9 & & Alavayal & & $\mathrm{P}$ & & \\
\hline & & & & & & \\
\hline 10 & & Kangumoola & & & & $\mathrm{P}$ \\
\hline 11 & & Karkkapaly & & & $P$ & \\
\hline 12 & & Edatheri & & & & $\mathrm{P}$ \\
\hline 13 & \multirow{3}{*}{ Puliyanparai } & Kottakunni & $\mathrm{P}$ & & & \\
\hline 14 & & Kappikadu & & $\mathrm{P}$ & & \\
\hline 15 & & Athur & & $\mathrm{P}$ & & \\
\hline 16 & Thorapally & Kunilvayal & & $\mathrm{P}$ & & \\
\hline 17 & \multirow{2}{*}{ Srimadurai } & Kutrimuchi & $\mathrm{P}$ & & & \\
\hline 18 & & Cherumulli & $P$ & & & \\
\hline
\end{tabular}

Table 1: Location of wetlands in different regions.

The surrounding forest type in Bennai and Chundi regions are predominantly evergreen habitat. Hence there are no ponds and agricultural areas are seen in these locations. Whereas the Padanthorai region falls in deciduous forests and most of the villages falls in agricultural fields. In Puliyanparai, Thorapally and Srimadurai regions falls under mixed type of deciduous vegetations and the adjacent villages does not have any ponds as well as agricultural fields.

\section{Materials and Methods}

Observations were carried out during the weekend days mainly from $0700 \mathrm{hrs}$ to $1500 \mathrm{hrs}$. Birds were identified with the help of pictures downloaded from the 
websites and also from the field guide [9] using Nikon $(8 \times 40 \mathrm{~mm})$ binoculars. Bird population was estimated using total count method [10]. In this method, representative wetlands were identified and birds in the areas were counted. Food and feeding behavior was investigated using the observational method [11]. Birds were observed in the field directly to record the feeding behavior.

Bird species were classified as: resident (R) - found in all suitable habitats throughout the study period; migrant (M) - found only during a specific season; local migrant (LM) - resident straggler from the hill (SH) - species usually found in the hilly areas of the state but recorded from this area; and vagrant (V) - birds which accidentally came to the region from its normal range, which is hundreds of miles away. According to the feeding habits, birds were divided as aquatic herbivores, aquatic insectivore, aquatic omnivores, piscivores, carnivores, insectivores and omnivores [12].

\section{Results and Discussion}

The wetland birds in the study sites were observed all the five months from October 2013 to February 2014 and it shows that the pond ecosystem is mostly preferred by the water birds followed by river and stream habitats. The agriculture fields were least preferred habitat since most of the birds species sighted were picivorous Table 2 . Different birds seen in different micro habitats including pond ecosystem, river, stream and agricultural field's shows that most of the bird species seen in ponds followed by river and stream. Only few bird species were seen in agricultural field Figure 1. Lower species richness of birds in this area is attributed due to the smaller size of the wetland [13]. As reported earlier from the Western Ghats, highest number of birds was recorded during the months of winter and there was a reduction in population size during the monsoon [14]. Many factors, which threaten the wetland ecosystem and in turn the bird population, were identified during the study. Birds use wetlands as a source of drinking water and for feeding, resting, shelter and social interactions [15]. Pollution, mainly from the chemical effluents is the major threats faced by birds in this ecosystem. These study areas are one of the major feeding grounds of many water birds and other resident species. The local people use water that has leaked out from this tank for agricultural activities and there by this polluted water would reach all the adjoining bird visiting areas. During summer season the local dwellers empty the scanty water bodies and catch fish. Uncontrolled fishing depletes the food sources of wetland birds. Small sized gill nets are used for fishing which results in the removal of even small sized fishes, indirectly affecting the availability of food for birds.

\begin{tabular}{|c|c|c|c|c|c|c|}
\hline Sl. No. & Name & Scientific Name & Pond & River & Stream & Agri. Field \\
\hline 1 & Black bittern & Dupetorflavicollis & $\mathrm{P}$ & $\mathrm{P}$ & $\mathrm{A}$ & $\mathrm{P}$ \\
\hline 2 & Blue-eared kingfisher & Alcedomeninting & $\mathrm{P}$ & $\bar{A}$ & $\bar{A}$ & $\bar{A}$ \\
\hline 3 & Cattle egret & Bubulcus ibis & $\mathrm{P}$ & $\mathrm{P}$ & $\mathrm{P}$ & $\mathrm{P}$ \\
\hline 4 & Common myna & Acridotherestristis & $\mathrm{A}$ & $\mathrm{A}$ & $\mathrm{P}$ & A \\
\hline 5 & Coot & Fulicaatra & $\mathrm{P}$ & $\mathrm{P}$ & A & A \\
\hline 6 & Grey wagtail & Motacillacinerea & $\mathrm{P}$ & $\mathrm{P}$ & $\mathrm{P}$ & $\mathrm{P}$ \\
\hline 7 & Jungle myna & Acridotheresfuscus & $\mathrm{A}$ & $\mathrm{A}$ & $\mathrm{P}$ & $\mathrm{A}$ \\
\hline 8 & Little egret & Egrettagarzetta & $\mathrm{P}$ & $\mathrm{P}$ & $\mathrm{P}$ & $\mathrm{P}$ \\
\hline 9 & Pied wagtail & Motacillamaderaspatensis & $\mathrm{P}$ & $\mathrm{P}$ & $\mathrm{P}$ & $\mathrm{P}$ \\
\hline 10 & Pied kingfisher & Cerylerudis & $\mathrm{P}$ & $\mathrm{P}$ & $\mathrm{P}$ & A \\
\hline 11 & Pond heron & Ardeolagrayii & $\mathrm{P}$ & $\mathrm{P}$ & $\mathrm{P}$ & $\mathrm{P}$ \\
\hline 12 & Red-wattled lapwing & Vanellusindicus & $\mathrm{P}$ & A & $\mathrm{P}$ & A \\
\hline 13 & Sand plover & Charadriusmongolus & $\mathrm{P}$ & $\mathrm{P}$ & $\mathrm{P}$ & $\mathrm{P}$ \\
\hline 14 & Shoveler & Anasplatalea & $\mathrm{P}$ & $\mathrm{P}$ & $\mathrm{A}$ & A \\
\hline 15 & Small blue kingfisher & Alcedoatthis & $\mathrm{P}$ & $\mathrm{P}$ & $\mathrm{P}$ & $\mathrm{P}$ \\
\hline 16 & $\begin{array}{l}\text { White breasted } \\
\text { kingfisher }\end{array}$ & Halcyon smyrnensis & $\mathrm{P}$ & $\mathrm{P}$ & $\mathrm{P}$ & A \\
\hline 17 & $\begin{array}{l}\text { White breasted } \\
\text { waterhen }\end{array}$ & Amaurornisphoenicurus & $\mathrm{P}$ & $P$ & $\mathrm{P}$ & $\mathrm{P}$ \\
\hline 18 & Yellow wagtail & Motacillaflava & $\mathrm{P}$ & $\mathrm{P}$ & $\mathrm{P}$ & $\mathrm{P}$ \\
\hline
\end{tabular}

Table 2: Wetland birds sighted in different micro habitats. 

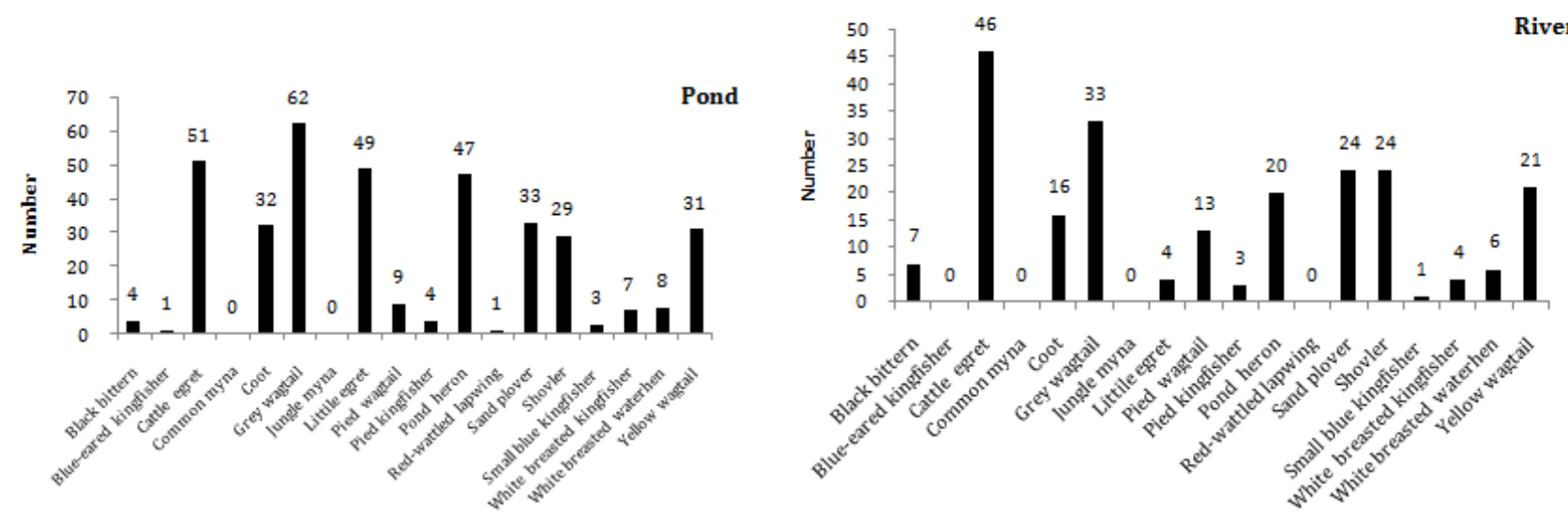

Bird species
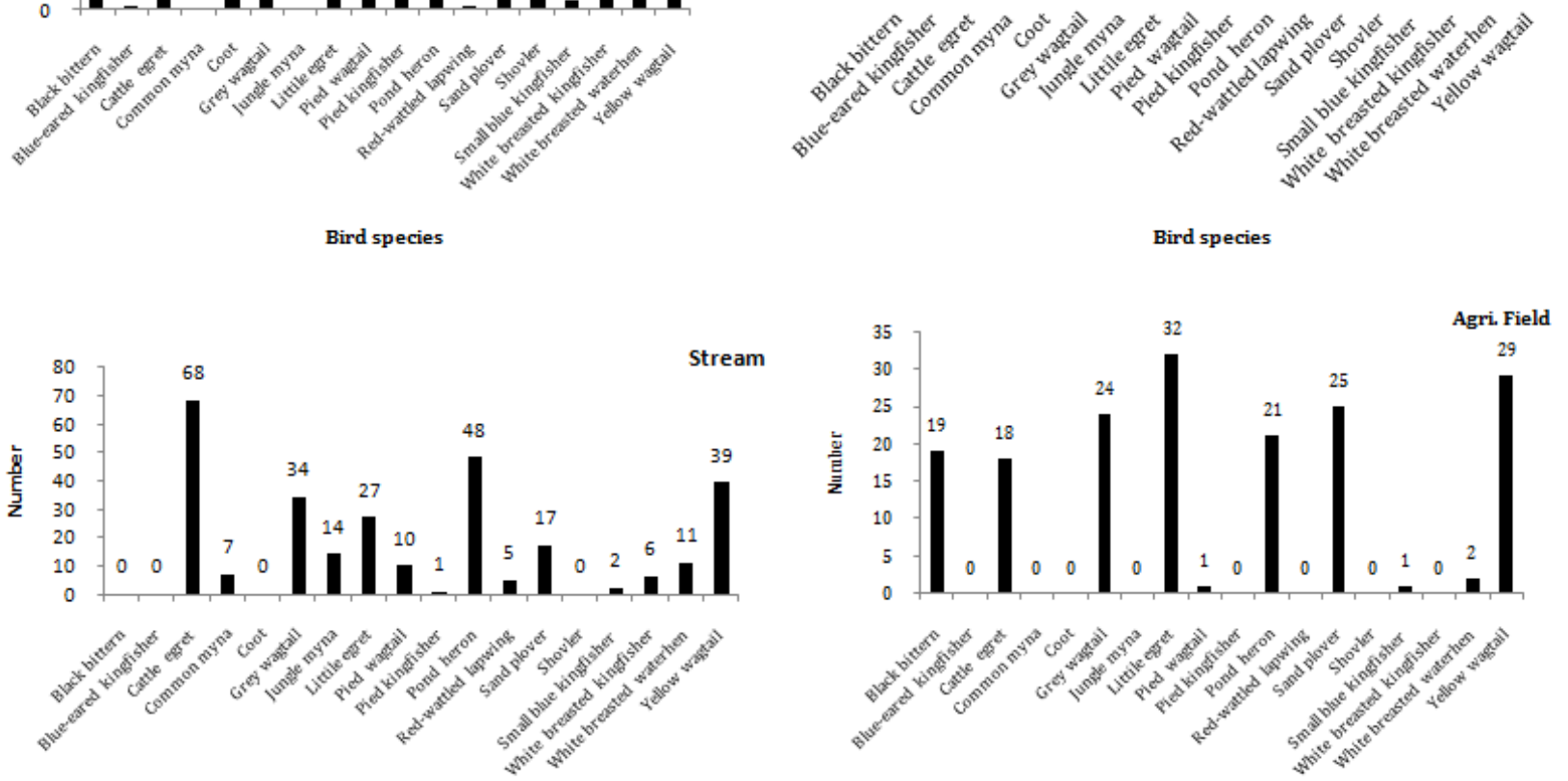

Bird species

Bird species

Figure 1: Number of bird species seen in different micro habitats.

Overall analysis of the birds sighted in all five months are shown that the cattle egrets were sighted more in number (176) followed by little egret (132), grey wagtail (125). Pond heron (97), Sand plover (89) and Yellow wagtails (84) were seen moderately. Only few sightings were recorded of blue eared kingfisher, small blue king fisher and red-wattled lapwing Figure 2 .

The Shannon index $\left(\mathrm{H}^{\wedge}\right)$ shows there is no much variation within the habitat types. Likewise the dominance (D) within the habitat types has a slight variation Table 3. The data analysis was also shown that most number of birds was seen during November month followed by January and October. Very low sighting of wetland birds seen during February month where there was shortage of water during this period Figure 3.

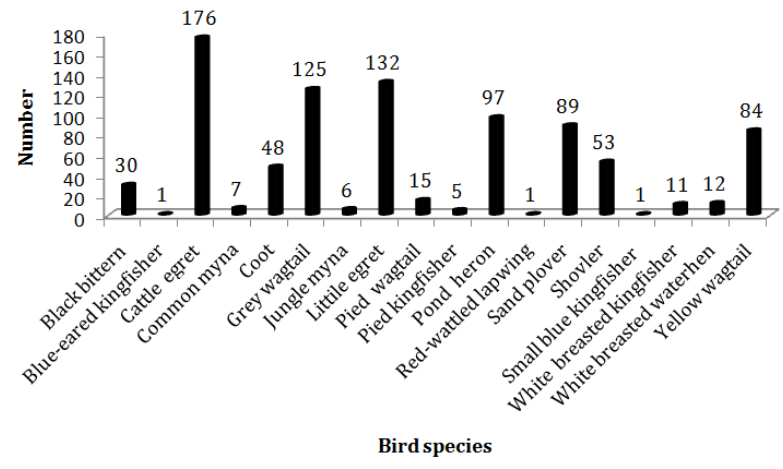

Figure 2: Overall sighting of wetland birds in the study sites. 


\begin{tabular}{|c|c|c|c|c|c|}
\hline $\begin{array}{c}\text { Eco } \\
\text { system }\end{array}$ & $\begin{array}{c}\text { No. } \\
\text { of } \\
\text { species }\end{array}$ & $\begin{array}{c}\text { Total No. } \\
\text { of } \\
\text { individuals }\end{array}$ & $\begin{array}{c}\text { pominanceShannon } \\
\text { (D) }\end{array}$ & $\begin{array}{c}\text { (Hevenness } \\
\left(\mathbf{H}^{\wedge} \mathbf{H} / \mathbf{S}\right)\end{array}$ \\
\hline Pond & 16 & 371 & 0.11 & 2.35 & 0.66 \\
\hline River & 14 & 222 & 0.12 & 2.32 & 0.73 \\
\hline Stream & 14 & 289 & 0.13 & 2.23 & 0.67 \\
\hline $\begin{array}{c}\text { Agri. } \\
\text { Field }\end{array}$ & 10 & 172 & 0.14 & 2.02 & 0.75 \\
\hline
\end{tabular}

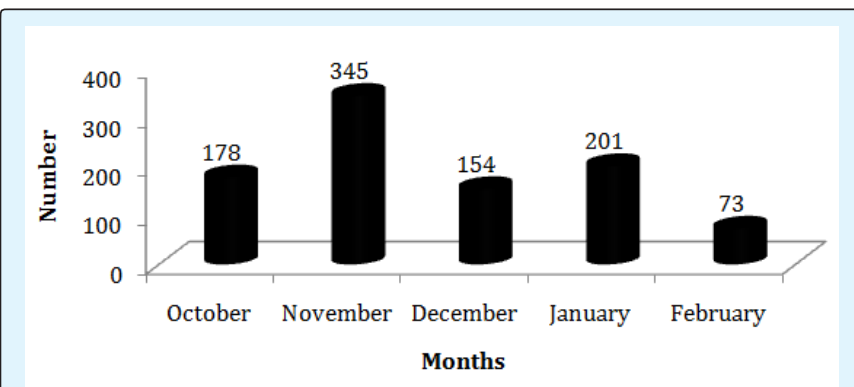

Table 3: Shannon index variation within the habitat types.

Figure 3: Wetland birds seen in different months in the study area.

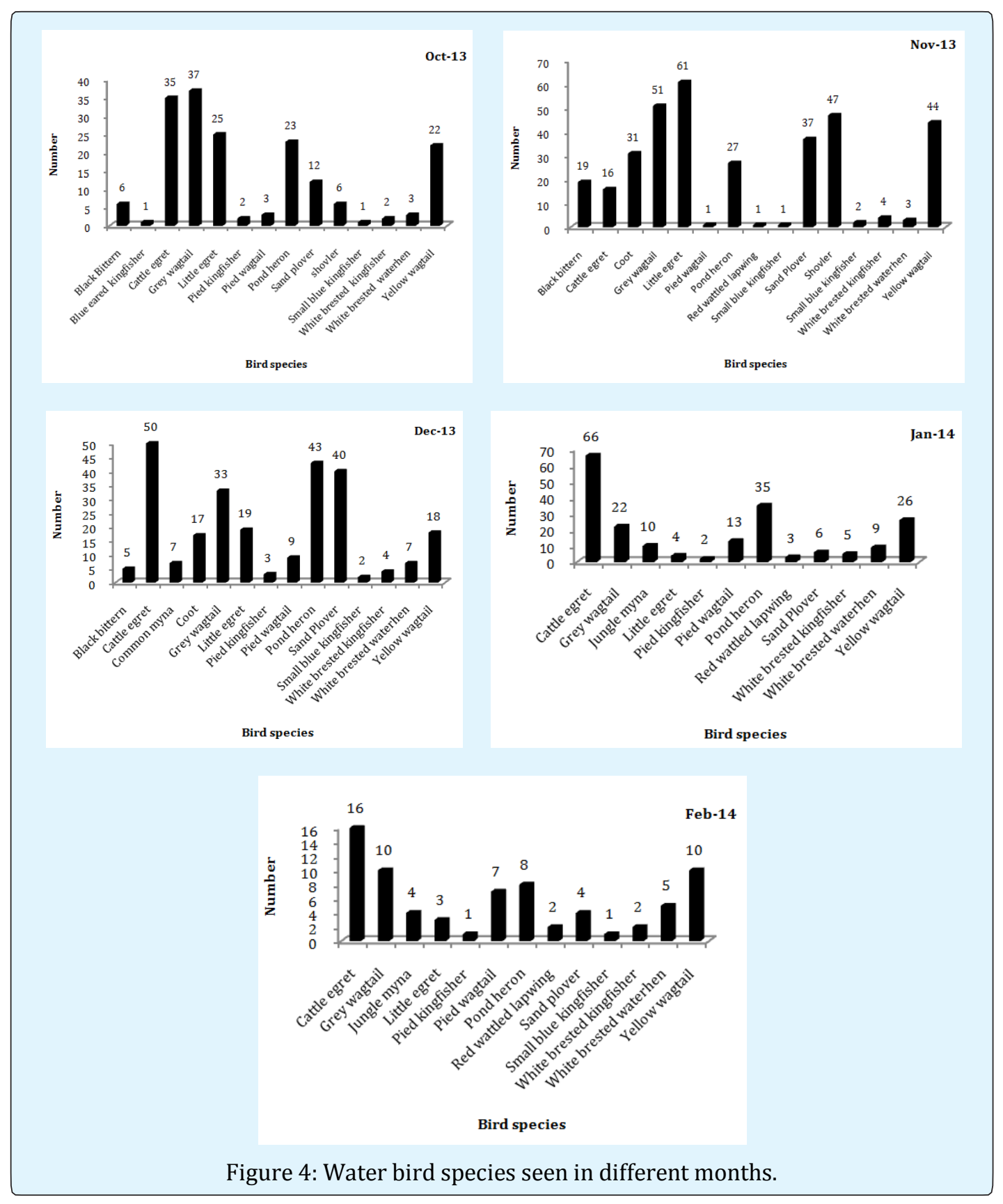


The bird species were seen in different months during the study period is shown in the Figure 4. It shows that the water birds were seen mostly during November and least sighting during February. The Shannon index $\left(\mathrm{H}^{\wedge}\right)$ shows there is no much variation with the months. Likewise the dominance (D) within the month shaves a huge variation Table 4.

\begin{tabular}{|c|c|c|c|c|c|}
\hline Months & No. of species & $\begin{array}{l}\text { Total No. of } \\
\text { individuals }\end{array}$ & Dominance (D) & Shannon $\left(\mathrm{H}^{\wedge}\right)$ & Evenness $\left(\mathrm{e}^{\wedge} \mathrm{H} / \mathrm{S}\right)$ \\
\hline Oct. 13 & 13 & 176 & 0.14 & 2.11 & 0.64 \\
\hline Nov. 13 & 14 & 344 & 0.11 & 2.24 & 0.67 \\
\hline Dec. 13 & 14 & 257 & 0.12 & 2.27 & 0.69 \\
\hline Jan.14 & 12 & 201 & 0.18 & 2.03 & 0.63 \\
\hline Feb.14 & 13 & 73 & 0.12 & 2.29 & 0.76 \\
\hline
\end{tabular}

Table 4: Shannon index variation within different months.

The micro habitat ecosystems including ponds, rivers, streams and agricultural field in different villages in Gudalur region are given in the Figure 5. More number of birds seen in pond followed by river and stream micro habitats. Very few bird species were seen in agricultural fields Figure 6.

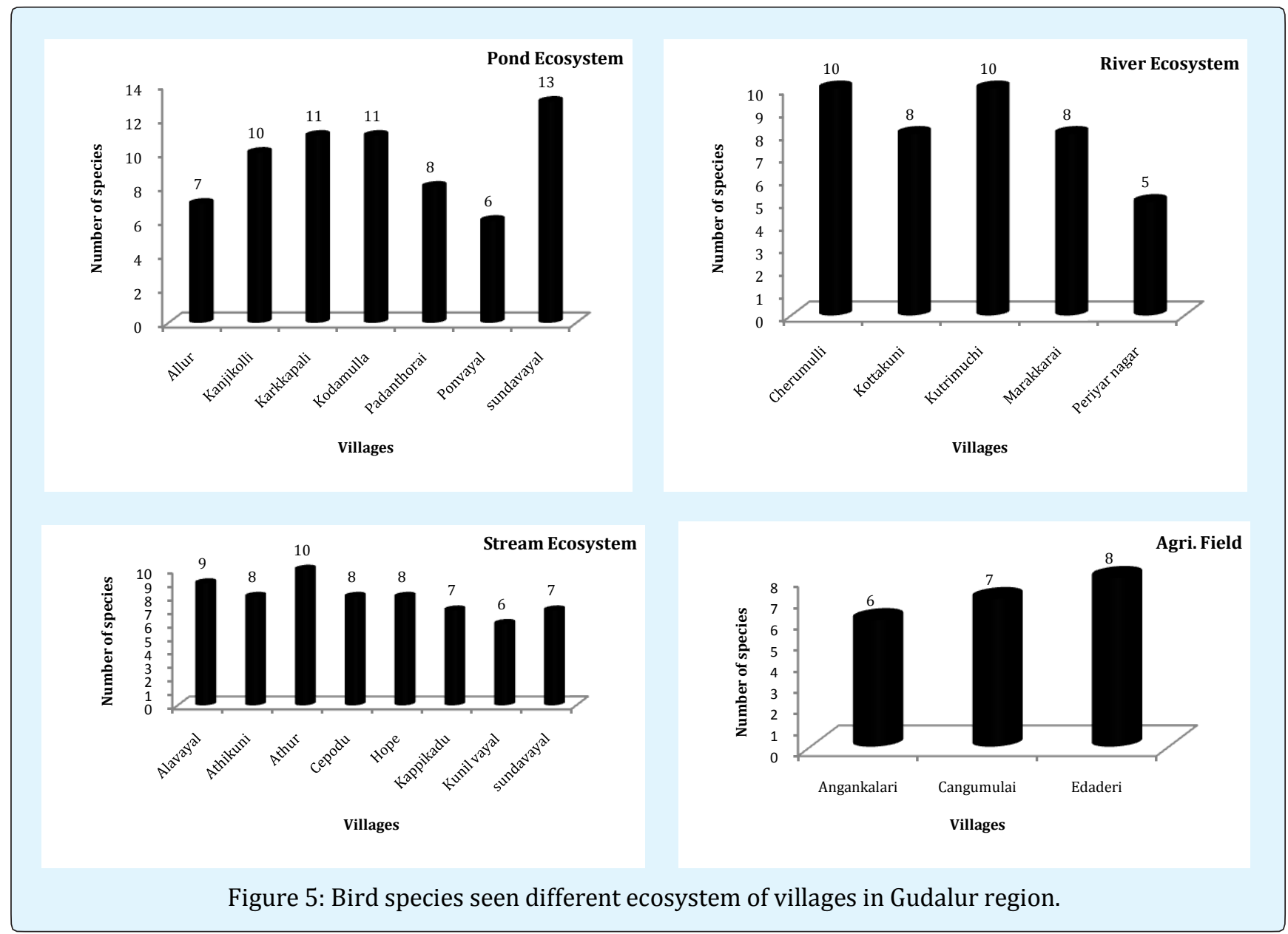




\section{International Journal of Zoology and Animal Biology}

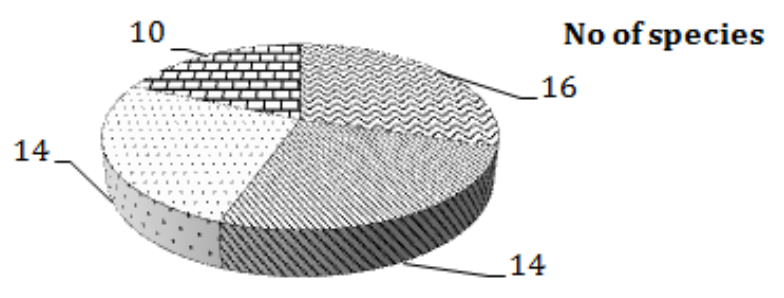

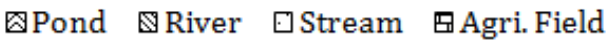

Figure 6: Number of bird species seen in different habitat types.

A dominant trend of bird-count exercises undertaken in India has been a focus on endangered birds, wetland birds, heronries and birds found in conservational significant terrestrial habitats. Adherence to methodological assumptions has been lax in many cases. In many water bird-counts, guesses or unjustified extrapolations have been made and in many large-scale transect studies, the nature of the function between detectability and distance of sighting away from the transect has been ignored. This can often result in inaccurate density estimates. Most studies have failed to test the reliability of count estimates by comparative studies. 'Encounter rates' have been a popular method for large birds.

\section{Conclusion}

While the emphasis on endangered birds and highvalue habitats is understandable, and also justified on account of their conservation significance, census of the common birds has generally been ignored. A standardization of census techniques using common birds would yield useful information in understanding biases inherent in sampling bird populations in the Indian context, and it could also be possible to experiment with a number of different techniques.

In community studies involving bird-counts, the absence of serious attempts to standardize 'efforts' by developing species-incidence curves is a serious drawback. Indeed, such an exercise would be valuable for bird at lasing projects that would be undertaken in future. Well-known governmental and non-governmental organizations have a greater role to play in training and educating amateur birdwatchers.

The study proved that if the present ecological characteristics of this wetland continue, the birds were unable to inhabit this habitat in the immediate future. Proper awareness class regarding the importance of birds to the local people, through different programmes will ultimately help the protection of birds of this region.

\section{References}

1. Mitsch WI, Gosselink IG (1986) Wetlands. Van Nostrand Reinhold, New York.

2. Buckton S (2007) Managing wetlands for sustainable livelihoods at Koshi Tappu. Danphe 16(1): 12-13.

3. Maltby ER (1986) Waterlogged Wealth: Why Waste the World's Wet Places? Earth scan, London, UK, pp: 132.

4. Unni KS (2002) Wetlands of India In: Proceedings of the National seminar on ecology and conservation of wetlands. Limnological Association of Kerala, pp: 1-5, 102.

5. Maltby ER, Turner RE (1983) Wetlands of the world. Geographical Magazine 55: 12-17.

6. Mitsch WJ, Gosselink (2000) Wetlands. John Wiley \& Sons Inc, United States of America, pp: 356.

7. Weller MW (1999) Wetland Birds Habitat Resources and Conservation Implications. Press syndicate of the University of Cambridge, United Kingdom, pp: 137.

8. Stewart RE (2001) Technical Aspects of Wetlands Wetlands as Bird Habitat. National Water Summary on Wetland Resources. US Geological Survey, pp: 86.

9. Grimmett R, Inskipp C, Inskipp T (2000) Birds of the Indian Subcontinent. London: Oxford University Press pp: 384.

10. Hoves JG, Bakewell D (1989) Shore Bird Studies Manual. AWB Publications 55: 362.

11. Altman J (1974) Observational study of behavior: sampling methods. Behaviour 49(3): 227-267.

12. Narayanan SP, Thomas AP, Sreekumar B (2011) Ornithofauna and its conservation in the Kuttanad wetlands, southern portion of Vembanad-KoleRamsar site, India. Journal of Threatened Taxa 3(4): 16631676.

13. Gajardo AG, Sepulveda PV, Schlatter R (2009) Water bird assemblages and habitat characteristics in wetlands: influence of temporal variability on 


\section{International Journal of Zoology and Animal Biology}

species-habitat relationships. Water birds 32(2): 225233.

14. Daniels AJR (1998) A field guide to the birds of south western India, Oxford University press, New Delhi, pp: 217.
15. Steward RE (2007) Technical Aspects of Wetlands: Wetlands as Bird Habitat: United States Geological Survey Water Supply Paper pp: 24-25.

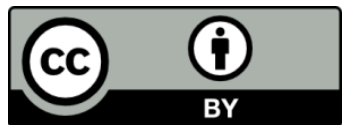

